\title{
THE CONTENT OF YOUTH EDUCATION IN KARAKALPAK FAMILIES BASED ON FOLKLORE
}

\author{
Amangul Doskhodjaeva \\ Senior teacher of the department of "General pedagogy and psychology" \\ Nukus state pedagogical institute named after Ajiniyaz
}

Article DOI: https://doi.org/10.36713/epra7273

DOI No: 10.36713/epra7273

\begin{abstract}
Like all peoples of the world, the Karakalpak people have always paid great attention to the upbringing of children in the family. The upbringing of a child in the family, is considered to be an integral part of life. Good results can be achieved if this process is carried out using the oral traditions of the people. Art of folklore traditions tested in the life of the people have been a spiritual food for thousands of years and serve as a tool of folk pedagogy and education. It is analyzed that folklore is the rich educational tool which used by the Karakalpak people in the upbringing of children.
\end{abstract}

KEY WORDS: Karakalpak people, family, upbringing, oral folklore, children's songs, national traditions, spirituality

\section{INTRODUCTION}

Like all peoples of the world, the Karakalpaks pay great attention to upbringing children in a family. People of Karakalpakstan widely used oral folklore samples for the effective implementation of upbringing children in the family. The question of upbringing a child in a family began at birth. The process of the primary upbringing of a child, purposefully expected in the family, was carried out through maternal love.

\section{METHODS}

Lullaby is a genre of oral folk literature. Lullabies are the basis for upbringing a child, which are closely related to the spiritual development of a deeply meaningful human life. The reason - love, hope, confidence in a child, lullabies arising from maternal love, which has reached every maternal happiness, or a new family member, a lullaby, emanating from the love of each family member for the expected child, affects the accumulation of spiritual substances, like happiness. The spirituality of a child is divided into emotions, deep feelings, and also love and good qualities are manifested in him. Nothing can replace this education, which began in the family. There are several units in lullabies that are concentrated in a very strong, pleasant voice that also attracts adults.

\section{RESULTS AND DISCUSSIONS}

The first is the love of a mother and a relative, the second is a pleasant voice that is necessary for the child's body, the third is the attitude towards the baby, upbringing, the trust given to him as a continuer of human life, the load is not only a simple song, but also a teaching tool.

$$
\begin{aligned}
& \text { Aynalayin appaǵim, } \\
& \text { Qozı júnli qalpaǵim, } \\
& \text { Qozim meniń gúl bolǵay } \\
& \text { Jiynaǵanim toy bolǵay } \\
& \text { Toyim-toyǵa ulasqay } \\
& \text { Da’wlet kelıp ornasqay [1; p. 7]. }
\end{aligned}
$$

In our example, the lullaby is one of the lullabies that have been active since ancient times. The dreams of a mother rocking the cradle make the baby look like a delicate beautiful flower, like a beloved lamb. These comparisons are an explanatory artistic tool recognized by pastoralists. There are also words for a mother to caress her baby. In lullabies with good intentions, she represents the future of her child, she wants to see his good days and arrange weddings. 
The task and intention that parents put in the family are very high, and the child begins to grow from the cradle. The upbringing that begins with the diaper gradually develops. A newborn baby does not understand the content of lullabies, only hears music with a pleasant voice. A pleasant sound affecting the child, soothes him and puts him in a sweet sleep. Through the lullaby, the child receives spiritual nourishment. Lullabies, which are closely related to human life, are accompanied by music that reveals the secrets of the mother. An example of lullabies that appeared in past centuries:

$$
\begin{aligned}
& \text { Menıń balam baldaydı } \\
& \text { Beline sadaq baylaydı } \\
& \text { El shetıne jaw kelse } \\
& \text { Dúrkıretıp aydaydi [4, p. 257] }
\end{aligned}
$$

The mother loves her sweet child. When he grows up, he will be a brave young man who will protect his people from enemies by repeating these duties while the child is in the cradle. Foundations of education, born in the cradle, seek solutions to the problems of their time. We can also see these traditional ways in modern examples of lullabies.

Hayda, hayda haydasin -ay

Aralim meniń jarali-ay

Qayta tolip Aralim-ay

Molaysin balam shadli toy-ay

A'miwimnen aqqan suwlar

Ilaylansin jan balam-ay

Eli-xalqimnin' nesibesi

Moldan bolǵan jan balam-ay [2. p.95].

This is what is recognized in our time by the fate of the Aral Sea, which suffered from an ecological disaster. A mother's dream of replenishing the sea, for her future child, in addition to a lullaby, is looking for a solution to the problems of that time. Or in the lullabies of some mothers who could not get along with their loved ones:

Qizim meniń quralay-ay

Qulaǵińda júp sirǵa-ay

Suwgeni bolǵay bir mirza-ay

Men bolayın bir irza-ay

Haya-haya, haydasi-ay [4. p.59]

So she wishes happy to her daughter.

Every day a growing child tries to walk. Parents look at these things with great attention, caution, and carry out a traditional ritual in the family "Tusaw kesiw" (Pruning of fetters). This is the cutting of the fetters on the legs, symbolizing the beginning of a new stage in the child's life - the ability to walk, to learn about the world.

In the song «Tusaw kesiw» among the child's relatives, a rich, energetic man cuts the child's restraint on the legs.:

Ǵaz-ǵaz balam, ǵaz balam

Qurısqan boydi jaz balam,

Gúrmewińdi sheshey1k,

Tusawıńdi keseyık,
Qutlı bolsın qádemıń

Kóz tımesın túkıreyık

Ómırge ayaq basa ber

Asiwlardan asa ber

Xalıqshil bol erinbe

Ilger1 bas sheginbe [4. p.25]

There is great concern and purpose in this rite for the child. This is how folk pedagogy lives in folklore, which is aimed at making a child a correct, educated and big person.

In the family, the child gradually begins to understand the functions, the meanings of words. His dedication to life prompts him to begin studying the alphabet of the philosophy of life. People who deeply understand such needs of a child in the family gradually brought him to the structural stages of life, creating children's songs, poems, fairy tales, riddles, legends, proverbs dedicated to children in folklore.

In Karakalpak folklore, there are several songs dedicated to children, for example, "Há túlkıshek, túlkıshek", "Há túyeler, túyeler", “Áwelemendúyelemen", "Ertek", "O’tirik ólen", "Shaq shaǵala", "Hákke qayda". Many of these songs are performed with games in the form of dialogue. The culture of language development, speaking on the basis of these songs, which are sung in a fun, humorous and light form dedicated to children, love for the Motherland, learning to work, virtue, the fight against arrogance and cruelty.

For example, in the song "Há túlkıshek, túlkıshek":

- Há túlkıshek, túlkıshek

Túnde qayda barasań?

- Mamamniń úyine baraman.

- Mamań saǵan ne berer?

- Eshkı sawıp sút berer?

Eshkısınıń sútı joq,

Ilaǵınıń putı joq.

Taram-taram et berer.

- Onı qayda qoyasań?

- Tal túbine qoyaman.

- Iyt alıp ketse ne q1lasań?

- Iyt awzınan alaman,

Batıy xanǵa baraman.

- Batıy xanniń nesı bar?

Ushar-ushar qusı bar.

Ushıp kettı hawaǵa

Qaytıp tústı darıyaǵa

Darıya suwın qurıttı

Aq shabaǵın shırıttı

Bır baydıń jurtında

Ekı tıshqan uristı

Saqal murtın julıstı [1. p.11].

In a series of songs dedicated to children in folklore, such songs in the form of questions and answers about the character of the child develop the child's ability to remember. They are taught to understand the content of the question and answer it clearly. Light humor focuses on teaching fiction 
through satire, introducing the characters of characters, and teaching the truth in life through the imagery of the protagonist.

We know from history that from the 11th-12th centuries to the 14th century, when the waterway along the open sea was opened, "Jipek Joly" (Silk Road) transported various valuables on camels, which were considered "ships of the desert" to China, India, Arabia and Europe, which gave them such a name.
-Ha’ túyeler, túyeler,
Duziń qayda túyeler?
Balqan tawdiń basinda
Balıq oynar tusında
Jemısım jerge tógildi,
Jer jusanın berdi.
Jusandı qoyǵa berdim,
Qoy qoshantayın berdı.
Qoshataydı qonaqqa berdım,
Qonaq qamshisin berdi
Qamshısın kólge tasladım,
Kól súwregın berdı
Suwregın ǵazǵa berdim
Ǵaz máyegın berdı [4. p.61].

The person who sings the song is talking to the camels. An artistic, convincing understanding of the interconnected system of nature is expressed in relation to the child. The method of explaining units of the surrounding world, objects, embodied in the language of animals, birds in oral folk literature, is especially widely used in expanding, developing the horizons of children.

"Áwelemen-dúyelemen" - this song is also popular among the people. This indicates that Arabic and Persian became the norm of the literary language until the 19th century. "Awelemen birinshi men, duwelemen ekinshi sen" is a word in Persian dedicated to teaching children to count in the usual way, if there are two, three, four children in a family, then they are spent opposite each other touching each other with bare feet and counting with fingers.

Áwelemen, dúwelemen

Salqan iyttıń sanı menen

Qara qoydıń qanı menen

Awez molla qayda kettı?

- Duzǵa kettı.

- Qashan keler?

- Jaz keler

Jaz kelmese gúz keler

Pállem push

Qashsan' qash.

Sen tur,

Sen shiq [4. p.50].

In this song, which is sung with the game, children learn that they have nine, or the number of toes, the spring season in which Auez Mulla competed last season, and that there are four seasons in a year. Our ancestors who lived before us in the past, using examples of the literary word, wisely brought up their descendants, prepared them for marriage, taught the secrets of life.

In oral literature, the plot of the song "fairy tale", dedicated to children, is close to the plot of the "Maqtanshaq pishiq" (boastful cat) in the folklore of the peoples of the world. But in the song we see a plot close to a child's concept, psychology, aimed at logical thinking, which teaches unity and connections on the path of knowing the world, leads to knowledge through the thin paths of science.

Ertegim erte boladi,

Qulaǵım kelte boladı,

Tirna jasawil boladı

Hákke biydumaq boladi.

Ol kúnge qarap sawal berıptı:

- Kún sen neden kúshlıseń?

- Men kúshlı bolǵanda bult basarma edı.

- Bult, sen neden kúshliseń?

- Men kúshlı bolǵanda jawın teserme edı?

- Jer, sen neden kúshlıseń?

-Men kúshlı bolǵanda tıshqan teserme edı.

Tishqan, sen neden kúshliseń?

- Men kúshlı bolǵanda pıshıq alarma edı.

-Pıshiq sen neden kúshlıseń?

-Men kúshlımen, kúshlımen,

Ayaǵımda zerlı gewısh,

Kúnde miń tıshqan sewish [1. p.16-17].

The song conclusion ends with a boastful feline bragging. In the song, a comparison of the forces of nature, their modest arrangement appears as an event of artistic poetics. The bright light of the sun, giant black clouds, rains, endless expanses understand that in understanding the earth, they have their own simplicity, interconnectedness. In oral folk literature, this song "fairy tale", thanks to its skill in creating images that reflect the amazing nature, has become an action-packed means of education.

The song "Hakke qayda" (Where forty) is also a song in the form of a dialogue in which children raise their voices and sing it through a verse in a disciplined manner with the characters. The appearance of the song associated with the magpie is also due to the fact that the prologue is made from the character of this bird, which revolves around people, around children, and it summarizes such views on how to set a goal correctly, not to be influenced by people like a magpie.

The song answers the questions:

- Hákke qayda?

- Uyasinda.

- Ne q11ıp atır?

- Keste tigip atır.

- Kestes1 qanday?

- Alaqanday.

- Dárwazanıń awızı qaydan?

- Óte beriń bunnan.

- Neshe atlasam ótemen? 
- Ek1 atlasań óteseń.

- Bir nan jeyseńbe?

- Jartı nan jeyseń be?

Bir nan jeymen.

Al onda basla[1. p.14]

Songs dedicated to children in folklore, accompanied by poems, carry a definite and educational meaning. This shows that creativity came from folk wisdom. Songs that are still meaningful to children throughout their lives serve as one of the main teaching aids. Among oral folk literature, there are also songs dedicated to children in a small form, in a way of narration, in the form of light humor.

\author{
Atı shawip baratır \\ Erı awıp baratır \\ Suwga kelgen qizlardıń \\ Kulkısı q1sıp baratır [2. p.86]. \\ Aspandaǵı juldızlar \\ Ay bolaman deyd1-yar \\ Zulayxaniń apası \\ Q1z bolaman deydi-yar [2. p.29]. \\ Shaq shaǵala shaǵala, \\ Japtıń boyın jaǵala, \\ Ilay suwda baliq bar, \\ Alalmaysań shaǵala [1. p.15].
}

These songs are taught to children by adults. Children recite it by heart. It is sometimes said that the children of both sides compete, reciting poetry, who knows how many songs. In games and in children's poems:

"Aspannan pishaq túst1,

P1shaq fashistiń ústine tústi.

Fashist ólemen dedi.

Saldat kómemen dedi"

These are words of curse pronounced against fascism, uttered from a child's language, describing the period of World War II in modern history. The songs of educational significance include adults who describe the consequences of a war that does not tear the child apart, giving rise to an anti-war character.

The wise people arose in the family even when raising a child with a speech impairment, especially speech, in the genre "Jan'iltpash" (proverb), which was carried out through rhyming verse words, repeating them with the help of exercises in the language. Such material, fixed in a special form, teaches you to pronounce letters and words correctly and clearly, and forms in the child the skill of repeated repetition of words. Song lines are expressed in rhymed form. The language of children often has difficulty pronouncing consonants such as R, S, T. Therefore, more often there are sayings in which these sounds are combined. In raising children with speech impairments, the people skillfully use samples of oral literature and sayings.

$$
\begin{aligned}
& \text { 1. Ayır atıńdı júk qartaytar } \\
& \text { Semiz qoydı may qartaytar }
\end{aligned}
$$

Úy qartaytar, búy qartaytar.

2. Qırda qırıq qırǵawıl,

Qırıq qırǵawıl ishinde,

Qırıq jıl qısır qalǵan,

Qızıl qıl quyrıqlı qırǵawıl.

3. Esiktiń aldı qara baraq,

Qarabaraqtıń ar jaǵı,

Qara qarabaraq,

Hámme qara qasqa baspaǵın,

Qarabaraqlandırmaǵa aparatır,

Mende qaraqasqa baspaǵımd,

Qarabaraqlandırmaǵa aparatırman $[1$, p.8]

During the religious holidays, the people perform children's songs in the genre "Aytym" (legend), which are performed on the New Year holidays - Navruz.
Aydar, Aydar
Q1rmanım tast
Áwmetım ast1
Qollaygór bizdi

Children were taught songs that have a poetic form, containing such expressions that are necessary at all times in a person's life, such as happiness, friendship, state, desire. For example: in order to cleanse his grains in autumn, asks Aydar, who is considered the god of wind, to give him the wind:

Men apamnıń tunǵıshıman

Qazan qırǵısh, qırǵıshıman,

Jawma kúnım, jawma! [2, p.42]

There is a popular belief that the one who gives birth to the first child will accept such a wish. On this basis, the people, performing songs of the legend both for themselves and for children, were brought up in faith in God the Creator. One of the legends that is performed on religious holidays is Yaramazan. The term of this song called "Yaramazan" refers to religious concepts at the beginning of the month of Ramadan, when people wish good intentions, when pronouncing these wishes, "Ya" is a sound that gives additional meaning to the word Ramazan in the introductory form, that is, language is the word marked at first sight, which gave rise to the word "Yaramazan". Ramadan, according to the religious understanding of our people, is a holy month. On one moonlit night of this month, there is an omnipotent night. It is believed that if someone sees the almighty night, he will be happy for the rest of his life. People fast in the month of Ramadan. With good intentions, the children recite the Ramadan songs.

Qazanıń qaqpaqlı bolsın,

Sıyırıń baspaqlı bolsın,

Paraxat balańız úylenip,

Úyiń1zde gúmbirlegen toy bolsin [2, p.4344].

Yaramazan aytıp keldi esıgıńe, 
Qoshqarday ul bersin besigińe

Ǵárezsizlık dáwırınde erkın jasap,

Qıdır darıp dáwlet bersin nesıbbeńe.

Yaramazan! [2, p. 107] - children enter the city and say good wishes. At the Navruz holiday, children, along with many folk poems, sing songs.

Jilaǵan kún joq bolıp,

Quwanǵan kún kóp bolıp,

Bawır pútın, bas aman

Jetkere bergey Nawrizǵa [2, p. 46].

The content of the songs of the legend is enriched by the wishes of the folk, ethnic and cultural nature, significant for humanity with the development of society, under the influence of the development of spiritual and life values in the minds of the people. Children, overshadowed by joyful feelings, are not limited only to games and songs. It influences the upbringing of children by spiritual, national traditions. Young people who have received such an upbringing from a young age will grow up in generations capable of ensuring the well-being of the people in the older generation.

"O'tirik o'len'" (False song), widespread in children's life, have an impact on the development of the child's consciousness at the symbolic level. The creation of false songs in oral folk literature is to teach children resourcefulness, eloquence and eloquence on a given topic - a lie.

Tuttım búrgenıń anasın,

Tutqa bayladım tanasın,

Qosqa qostım jupqanasın,

Jer súdıgar etpedimbe?

Bir búrge teptı dizeme,

Keldım altı ayda ózıme,

Inanbas adam sózıme,

Alt1 ay kesel jatpadımba? [1, p. 17].

False songs take a place in children's songs as the first elements of the art of eloquence, directing the child to a correct understanding of the world around him, knowing it with the help of artistic words. Whatever type of samples of oral folk literature we take, you will witness their rich content. Each of them is a masterpiece that is most actively used in the education of generations. In folk life, the wise words "education" have always been used from cradle to grave. The upbringing of younger adolescents is exclusively collective in nature, going beyond the family environment. In whatever period the Karakalpak people lived, young people, who gave priority to human upbringing, did not limit themselves to adult and children's games and songs. Heroism, openness, which belong to major epic genres, listened to the epics performed by jirau and bakshi. The artistic work of the talented, creative, executive jirau and bakshi was very influential and served as the main means of spiritual education of the people. Before jirau started a big dastan, until the people gathered completely, he tried to educate the younger generation by telling significant stories. For example:

Aǵań, ınıń bolmasa,

Arǵa shappaq ne payda,

Jan kúyerıń bolmasa

Jawǵa shappaq ne payda.

B1legımde kúshım bar,

Batırman dep maqtanba,

Baxit qondı basıma

Úlkeydım dep maqtanba,

Dún'ya jıyıp úyıńe,

Kórkeydım dep maqtanba,

Kóp maqtanǵan bolmaydı

Sózdıń shının aytqanda [1, p. 26-27].

The influence of such didactic terms is very strong, indicating the right path for a person who made a mistake. There is a custom among the people to decorate various joyful events in the family with wedding ceremonies. In such wedding ceremonies, national customs and ceremonies, known as "Bet ashar" (Opening the face), when the bride opens her face and greets her close relatives and parents, take a wide place. This tradition has a deep educational image in its content.

Dáwlet bolǵay úyımız,

Sáwbet bolǵay úyımız

Kelınshek kelse awilǵa

Shad bolar kewıl kúyımız,

Xızmette bolar kún-túnı,

Jası menen ǵarrısı,

El baslaǵan bıyımız

Toyǵa kelgen qonaqqa,

Toldı búgın úyımız.

Tegin emes biraq bul,

Hámmesı senı sinap tur,

Qalay eken kelın dep

Bir-brinen sorap tur

Boyınsınıp xalıq saltına,

Iybe saqlap tartına

Úlkenı menen kıshısı

Jası menen qartına

Quwanıshlı toyıńa

Jiynalıp kelgen xalqıńa

Jup sálem ber kelınshek!!! [2, p. 34]

Raising a young bride about the dignity of the family, the dedication of parents on the path of children, that kinship, love, respect are the most valuable qualities in a person's life, she decorates didactics with bright light, like a lantern on the way to creating a good family. This is a big factor pointing to the popular wisdom of how to bring up a bride who begins to build a new family. The reason is that she is the new bride, the mother who feeds the family, extends life by creating tomorrow's family members. The mother is the person responsible for raising the child in the family. 


\section{CONCLUSION}

Examples of oral literature describing the rich history of our people, folk pedagogy, ethnopedagogy, everyday life, life experience, views on justice and injustice of national culture, there are treasures that can serve as the basis for human education [3]. These are fantasies that run counter to normal life events and science. "Fairy tales-proverbs for good" - from artistic images on samples of oral literature to artistic details that affect a person, which can give him fair and correct decisions in conclusions.

\section{REFERENCE}

1. Tajimuratov A. Karakalpak folk pedagogy. Nukus: Bilim, 1996. - 140 p.

2. Karakalpak folklore. Many volumes. Vol. V. Karakalpak folk songs. Nukus: Karakalpakstan, 1980.

3. Ethnopedagogy of the Karakalpak people. Collection. Nukus: Bilim, 1995. - 104 p.

4. Tajimuratov Á. Karakalpak folk pedagogy. Nukus: Bilim, 1996. 